\title{
Physiological potential of soybean seeds treated with thiamethoxam and submitted to storage
}

\author{
Lilian Gomes de Moraes Dan ${ }^{1^{*}}$, Alessandro Lucca Braccini ${ }^{1}$, \\ Alberto Leão de Lemos Barroso ${ }^{2}$, Hugo de Almeida Dan ${ }^{1}$, Gleberson Guillen Piccinin ${ }^{1}$, \\ Juliana Marques Voroniak ${ }^{1}$ \\ ${ }^{1}$ Department of Agronomy, State University of Maringá, Maringá, Brazil; \\ *Corresponding Author: liliangmdan@yahoo.com.br \\ ${ }^{2}$ Department of Agronomy, University of Rio Verde, Rio Verde, Brazil
}

Received 18 July 2013; revised 18 August 2013; accepted 23 September 2013

Copyright (C) 2013 Lilian Gomes de Moraes Dan et al. This is an open access article distributed under the Creative Commons Attribution License, which permits unrestricted use, distribution, and reproduction in any medium, provided the original work is properly cited.

\begin{abstract}
Bio-activators such as thiamethoxam have been used to increase the productive potential of plants, by means of metabolic and plant morphology modifications. Nevertheless, very little is known regarding the effectiveness of this insecticide when incorporated into lower quality level soybean seeds, particularly during storage. The objective of this work was to assess the influence of thiamethoxam on the physiological potential of soybean seeds with different initial vigor levels during four storage periods. Three vigor levels of cultivar Anta-low (35\%), medium $(70 \%)$ and high (85\%) vigor-of soybean seeds were utilized in this experiment. The experimental design was completely randomized in a 3 $\times 2 \times 4$ factorial scheme-3 levels of vigor (low, medium and high); 2 seed treatments (with and without thiamethoxam) and 4 storage periods ( 0 , 30,60 and 90 days). The analyzed variables were: germination, first germination count, accelerated aging test, seedling length and emergence speed index. Thiamethoxam-treated soybean seeds benefit the physiological potential of both medium and high vigor seeds during storage up to 30 days. Whereas, the use of thiamethoxam was shown to be ineffective in improving the physiological quality of initial low vigor seeds.
\end{abstract}

Keywords: Glycine max; Bio-Activator; Vigor; Physiological Quality

\section{INTRODUCTION}

Soybean crops comprise both increased productive po- tential and adaptability in different regions of Brazil due to recent technological advances in the productive segment. Among the modern farming techniques, the incorporation of products such as fungicides and insecticides to seeds in order to protect the plants and increase the productive potential is becoming an increasingly widespread practice in most technified agriculture in advanced countries [1].

In general, insecticides are assessed for their efficiency on pest control; however, some products can cause effects yet unknown, modifying the metabolism and morphology of the plant [2]. The discovery of the molecule thiamethoxam (3-(2-chloro-thiazol-5-ylmethyl)-1,3,5oxadiazinan-4-ylidene-N-(nitro)amine) brought about new perspectives for agriculture, mainly regarding seeds' treatment. A number of studies have shown the efficiency of thiamethoxam as a bio-activator, promoting increments on germination, emergence, seedling length (roots and aerial parts) and dry phytomass. In addition, the product can eventually improve the performance of plants under stress, besides increasing total protein and enzyme content levels in plants [3]. Thiamethoxam proved to be efficient as a bio-activator, essentially for soybean seeds [4].

According to [5], thiamethoxam positive physiological effect is related to germination, vigor, enzymatic activity, nutrient level, height plant, stem diameter, radicular development, phytomass, pods' number per plant, grain weight and yield, providing an increment, on average of four bags per hectare of soybean. Increased vigor, productivity, leaf and radicular area index, a more uniform stand, emergence uniformity and better initial development of soybean seedlings were observed by [6].

Thiamethoxam used in soybean seed treatment, accelerates germination and induces further development 
of embryonic axis, minimizing the negative effects in situations such as presence of aluminum, salinity and water deficit. This acceleration of germination is due to the stimulation of peroxidase activity, preventing oxidative stress [7], thus, reducing the time of crop establishment in field, and therefore, lessening the harmful effects of either weed competition or essential nutrients present in soil [2].

Nevertheless, it is equally important to consider that the effectiveness of thiamethoxam treatment may depend, among a number of factors, on seed vigor at the time of product application. According to [8], the utilization of biologically active compounds such as bio-activators can either cease or reduce the impact of adverse factors on seeds' quality and performance. Moreover, one of the greatest limitations of soybean farming is unavailability of high-vigor seeds at the sowing time [9]. Additionally, little is known about the bioactive effect of thiamethoxam applied to initial low- or medium-vigor soybean seeds.

Another factor to be considered is that soybean seeds usually present reduction in physiological quality during long term storage [10], even under favorable conditions. In Brazil, the preservation of soybean seeds' quality during storage is among the largest obstacles for seed industry. According to [11], seed quality maintenance until sowing time ensures the increased emergence potential of seedlings in field, resulting in productivity gains. During storage, seed quality can either remain close to the initial level or reduce to a level which makes the seed unavailable for sowing. This fact is related to several circumstances, such as environmental conditions during seed production, occurrence of pests, oil content in seeds, water content, mechanical damages over the course of processing and packaging, temperature and relative humidity of the air during storage [12-14], besides chemical treatment of seeds using insecticides $[15,16]$.

Thus, thiamethoxam proved to be effective as a bioactivator on soybean seeds' treatment, implying the necessity to assess its effectiveness regarding its use in lower physiological quality level seeds, particularly during storage.

In this scope, this present study had the objective to assess the influence of thiamethoxam on physiological potential of soybean seeds with different initial vigor levels in four periods of storage.

\section{MATERIAL AND METHODS}

\subsection{Experiment Installation and Conduction}

This experiment was conducted at the State University of Maringá (UEM), Maringá, Paraná State, and assessments on physiological quality of seeds were carried out at the Laboratory of Seed Technology at the Applied Ag- riculture Research Nucleus (NUPAGRI), Center for Applied Agricultural Research of UEM.

Soybean seeds of cultivar Anta 82 RR from Adriana's Seeds - maturity group 7.4 and semi-determinate growth habit - were used in this study. Tetrazolium test was used for this cultivar [17] to select lots with three levels of initial vigor: low (35\%), medium (70\%) and high (85\%). The experimental design was completely randomized in a $3 \times 2 \times 4$ factorial scheme -3 levels of vigor (low, medium and high); 2 seed treatments (with and without thiamethoxam) and 4 storage periods $(0,30,60$ and 90 days).

Chemical treatment of soybean seeds was carried out using thiamethoxam (Cruiser ${ }^{\circledR} 350 \mathrm{FS}$ ), at a dose of $2 \mathrm{~mL}$ per kg of seeds.

Syrup (product + distilled water) was applied using a graduated pipette at the bottom of a transparent plastic bag and spread across its walls up to $15 \mathrm{~cm}$ high. The volume of syrup was $0.3 \mathrm{~L} 100 \mathrm{~kg}^{-1}$ of seeds. The witness received distilled water on the same volume of syrup with the insecticide. The quality of treated seeds was assessed at the following times: 0, 30, 60 and 90 days after soybean seed treatment.

\subsection{Assessed Features}

The following tests were carried out both at the laboratory of seeds and greenhouse using trays containing washed and sterile sand, and then utilized to assess the physiological quality of soybean seeds.

\subsubsection{Germination Test}

Four subsamples of 50 seeds were used for each lot and replicate use; they were then placed for germination between three-leaf germination paper imbibed in distilled water in a ratio of 2.5 times as much the paper dry mass. They were then rolled up and placed in a Mangelsdorf germinator kept at a constant temperature of $25^{\circ} \mathrm{C}$. Evaluations on the percentage of normal seedlings were carried out both on the fifth (first count) and eighth (final count) days, according to the established criteria of the Seed Analysis Rules [18]. First count was considered as an indicative of vigor and final count as the total seeds germination percentage.

\subsubsection{Accelerated Aging Test}

Plastic boxes (gerbox) provided with horizontal stainless steel screen fixed at the median position were used in this experiment. $40 \mathrm{~mL}$ of distilled water (in order to get approximately $100 \%$ of Relative Humidity) was added to the bottom of each gerbox, and seeds were uniformly distributed on the screen in order to cover its surface, forming a single layer. Subsequently, the boxes, together with the seeds, were sealed and stored in a Water Jacket Incubator and kept at a constant temperature of 
$41^{\circ} \mathrm{C}$ for 48 hours [19]. After this period, seeds were taken for germination under the same conditions described previously on germination test.

\subsubsection{Emergence speed index}

It was carried out from sowing in trays containg $8 \mathrm{~kg}$ of washed and sterile sand in 4 replicates of 50 seeds for each sample. Test was conducted at the greenhouse and emerged seedlings were counted daily between the onsets (five days after installation) of emergence until the numerical stabilization of the counts (ten days after installation). Emergence speed index calculation was accomplished in accordance with [20], using the formula proposed by [21].

\subsubsection{Seedling Length}

Five samples of 20 seeds from each treatment were distributed in germination paper rolls imbibed with distilled water in a $2.5: 1$ ratio $(\mathrm{mL}$ distilled water per dry paper mass in grams) and kept into a germination chamber at $25^{\circ} \mathrm{C}$ for five days [20]. A line was longitudinally traced in the upper third upon the humidified paper towel, where seeds were placed pointing the micropyle downward. Seedlings length which was considered normal [18] was determined at the end of the fifth day using a millimeter-gauged ruler.

\subsection{Statistical Analysis}

Variables which characterize the physiological quality of seeds were all submitted to variance analysis (ANOVA) using the Statistical Analysis System-SISVAR. Regression analysis was utilized to verify polynomial adjustment for dependent variables according to storage periods, at $5 \%$ probability [22].

\section{RESULTS AND DISCUSSIONS}

\subsection{Germination Assessment}

Significant interaction was shown for both treatment of seeds and periods of storage (Figure 1) by assessing the germination test results. For high and medium-vigor seeds, submitted or not to thiamethoxam treatment, reductions in germination performance over storage were similar. Nevertheless, taking into account the study accomplished by [7], thiamethoxam, used for seed treatment accelerated soybean germination, whose effect was pronounced when twice-fold dose of that recommended for the crop was utilized ( $4 \mathrm{~mL} \cdot \mathrm{kg}^{-1}$ of seed).

Furthermore, at 90-day storage, germination percentages were higher to $80 \%$ in both seed treatments assessed, thus being within the trading-accepted standards of soybean seeds in Brazil [23]. In thiamethoxam-treated soybean seeds any germination and vigor differences were found [24], as well as [25] who observed no germination

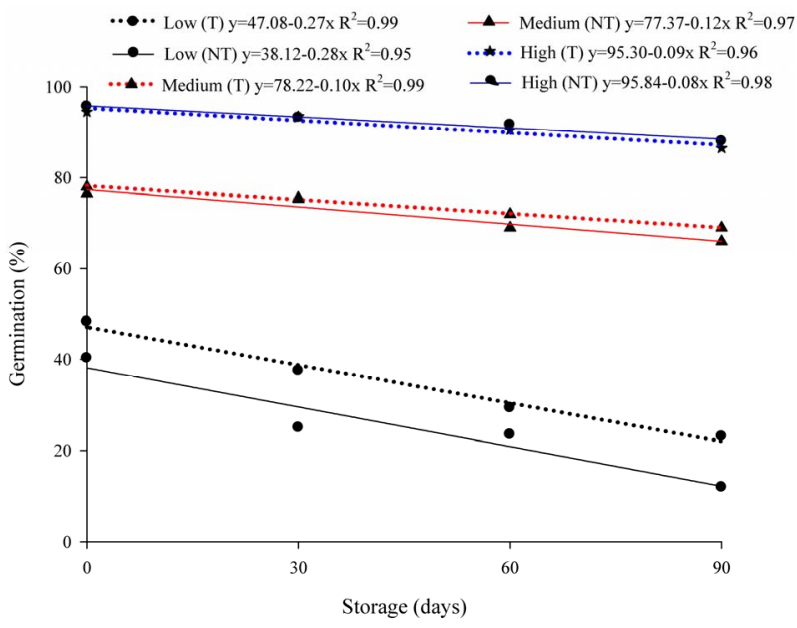

Figure 1. Polynomial regression for soybean seeds germination percentage with different levels of initial vigor, treated (T) and not treated (NT) with thiamethoxam in four periods of storage.

effects on bean seeds.

The lack of thiamethoxam positive effects on germinative performance in this current work may be on the basis of the recommended dose used for the crop (2 $\mathrm{mL} \cdot \mathrm{kg}^{-1}$ of seed). However, the choice for using the recommended dose in this study was mainly not only due to economic viability but also to environmental and ecological aspects related to chemical dose increments.

For low vigor thiamethoxam-treated seeds (Figure 1), $47 \%$ germination was observed in the onset of storage, whereas for non-treated seeds, germination level was $38 \%$. This fact shows the positive action of thiamethoxam treatment in low-vigor seeds, when not stored. Nevertheless, the effect of storage is negative for both treated seeds and for those which received no chemical treatment. These results are in accordance with [16] who observed that soybean seeds treated or not with thiamethoxam showed germination reduction over a 45-day storage.

\subsection{First Count of Germination Test}

Significant interaction between seed treatment and storage period (Figure 2) was observed at the polynomial regression assessment for normal seedling percentage in first germination count. In high-vigor soybean seeds, treatment using thiamethoxam and the witness showed normal seedling percentage of $0.15 \%$ and $0.14 \%$, respectively in each day's storage. Thus, demonstrating similarity to that reduction of physiological performance of initial high-vigor seeds among treatments during storage.

In both medium- and low-vigor seeds (Figure 2), reductions on normal seedling percentage in the first count were $0.10 \%$ and $0.17 \%$, respectively for each day's stor- 


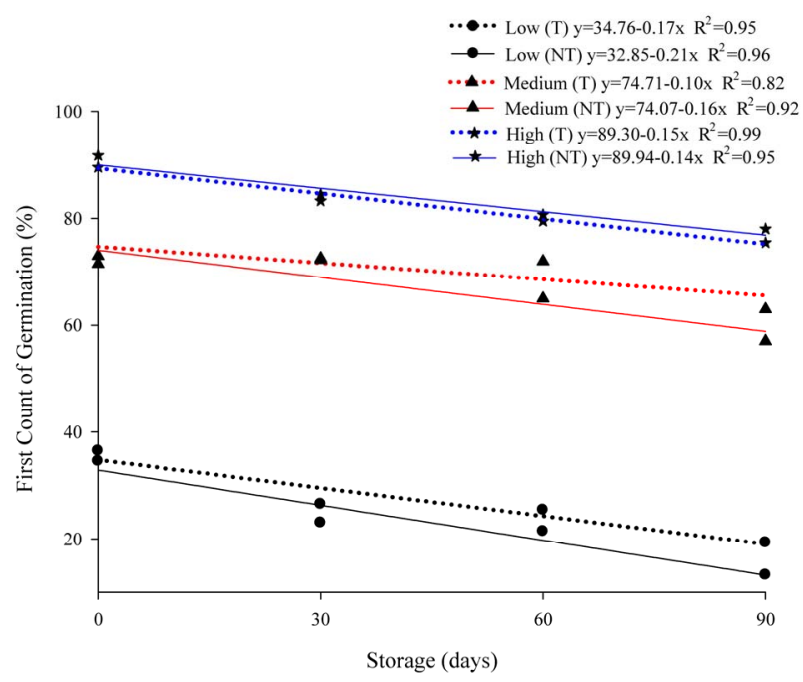

Figure 2. Polynomial regression for normal seedling percentage in the first count of soybean seed germination with different initial vigor levels, treated (T) and not treated (NT) with thiamethoxam in four periods of storage.

age for thiamethoxam-treated seeds. Whereas, for the witnesses (no chemical treatment), vigor decrements were $0.16 \%$ (medium vigor) and $0.21 \%$ (low vigor) for each day's storage. These results support thiamethoxam beneficial effects on vigor maintenance of soybean seeds with initial quality ranging from intermediate to low during storage [26], when working with cotton crops, concluded that higher increments are reached by using thiamethoxam in lower physiological quality seeds, particularly in vigor tests. Thiamethoxam promotes soybean seed expression related to both enzyme synthesis and activity by modifying amino acids of phytohormone precursors, resulting in an increase of germination, vigor and radicular growth [27].

Nevertheless, at day 90 of storage, only initial highvigor seeds showed normal seedling percentage over $80 \%$, despite the reduction observed along with storage period increment.

\subsection{Vigor Assessment in the Accelerate Aging Test}

Results on accelerated aging test (Figure 3) showed that in initial high-vigor thiamethoxam-treated seeds, decrement was more intense in normal seedling percentage during storage, ranging from $89.8 \%$ at the beginning of storage to $57.4 \%$ after 90 -day storage. On the other hand, assessment carried out right after thiamethoxam application (period zero) in seeds, percentages of $89 \%$ for vigor and $83 \%$ for treatment without the insecticide were observed. These results show that the positive effects on initial high-vigor soybean seeds is limited to short term storage when submitted to stress conditions in the accelerated aging test.

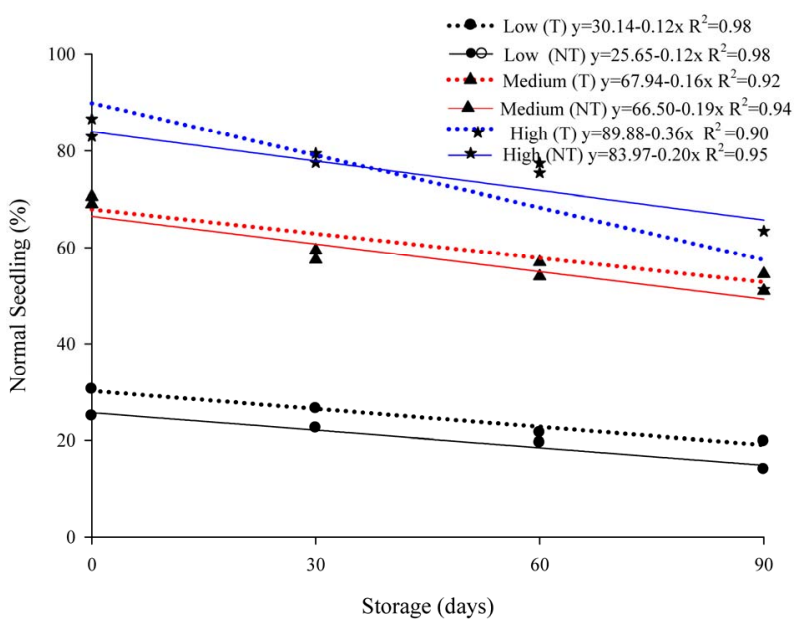

Figure 3. Polynomial regression for normal seedling percentage after accelerated aging test of soybean seeds with different initial vigor levels, treated (T) and not treated (NT) with thiamethoxam in four periods of storage.

In medium-vigor seeds, thiamethoxam incorporation via seed treatment presented positive action during storage because angular coefficient indicated $0.16 \%$ reduction on seed vigor for each day's storage. In contrast, for the witness, seed vigor decrease after accelerated aging test was $0.19 \%$ in each day of storage (Figure 3).

Accelerated aging test is one of the most used for physiological potential assessment of several species [28]. This test has as key principle lead to a considerable increase on seed deterioration when exposed to high levels of temperature and relative air humidity, which are considered preponderant environmental factors for both intensity and speed deterioration. It is notorious that stress conditions induce reactive oxygen species (ROS), which damage biomolecules, leading to cellular death. However, there are antioxidative enzymes such as superoxide dismutase and peroxidase which are responsible for ROS elimination. According to [7], thiamethoxam speeds up seed germination under stress conditions by eliminating the ROS generated. Thiamethoxam moves through plant cells and activates various physiological reactions, such as the expression of functional proteins related to defense mechanisms of plants against stress factors, for instance, water deficit, high temperatures, toxic effects, just to name a few [4]. Thus, the influence of thiamethoxam on these defense mechanisms and on antioxidative enzyme activities may have played a role against adverse conditions of high temperature and increased relative humidity imposed by the aging test, and therefore, having attenuated the physiological potential decrement of soybean seeds during storage.

In initial low-vigor seeds (Figure 3), the use of thiamethoxam showed no positive effects on the improvement or maintenance of seed vigor during storage for 90 days, once angular coefficient presented the same reduc- 
tion in both seed treatments (treated and not treated).

\subsection{Emergence Speed Index Assessment}

In the results of emergence speed index (ESI) (Figure 4), reductions observed upon this variable were also significant as storage period increased in both seed treatments. ESI reductions observed over the course of storage, initial high- and low-vigor seeds highlight thiamethoxam negative effect on soybean seedling emergence speed derived from treated seeds and submitted to storage. In contrast, this insecticide treatment in medium vigor seeds showed similar effect when compared to those of the witnesses on the ESI performance, presenting 0.05 reduction unit each day in which treated seeds were stored. These results are conflicting to those found by [4], who concluded that soybean seeds treated with thiamethoxam showed faster germination due to the action of the product that stimulates enzymatic activity, providing a more uniform and better initial seedling development.

\subsection{Seedling Length Assessment}

Soybean seedlings height (Figure 5) showed significant reduction $(p<0.05)$ as storage period increased in both seed treatments. In initial high- and medium-vigor thiamethoxam-treated seeds, reductions on seedling lengths in the order of 0.08 and 0.04 , respectively, were observed in each day of storage. In the witnesses, reductions of 0.04 and $0.03 \mathrm{~cm}$ were observed in each day of storage for high- and medium-vigor seeds.

Despite the highest reduction on this response variable during storage is determined in thiamethoxam treatment, seedling length was $4.94 \mathrm{~cm}$ taller than the witness for initial high-vigor seeds at the storage period onset (period zero).

In medium-vigor seeds, the maximum efficiency of the product, for this variable, enabled seedlings height to increase up to $3.0 \mathrm{~cm}$, comparatively to seeds with no product applications. Thus, that the bioactive effect of thiamethoxam in initial high- and medium vigor-seeds is limited to a 30-day storage period is evidenced. The thiamethoxam tendency to increase seedling length corroborates with the effect observed by [24] in soybean crop.

After a 30-day period, the natural aging process of seeds, which occurs during storage and culminates in physiological quality loss, negatively interferes in the thiamethoxam action in order to increase seedling growth. This fact can also be observed on results of seedlings derived from initial low-vigor seeds, treated or not with thiamethoxam, which showed the same reduction during storage. Thus, the absence of thiamethoxam positive influence on seedling length from low-vigor seeds may be

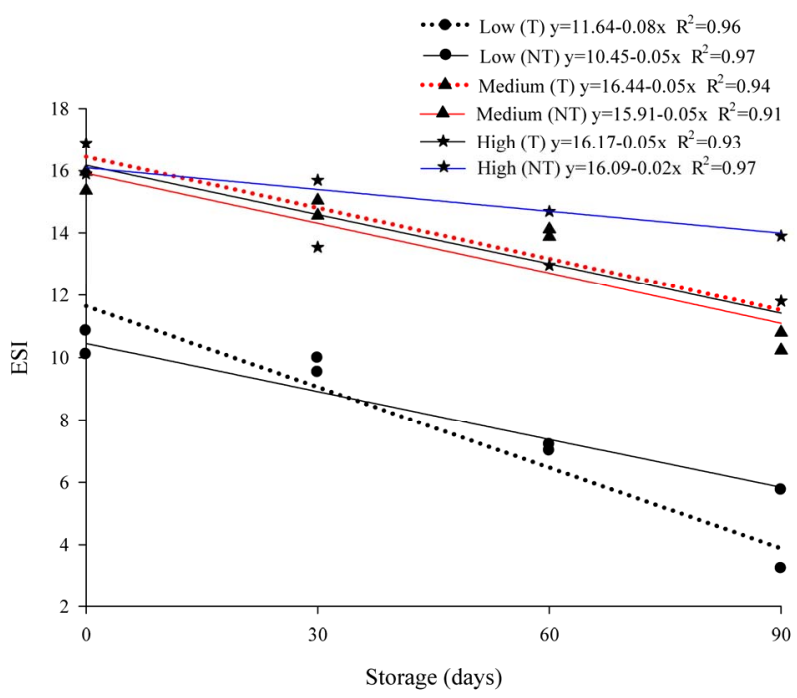

Figure 4. Polynomial regression for the emergence speed index (ESI) of seedlings derived from soybean seeds with different initial vigor levels, treated (T) and not treated (NT) with thiamethoxam in four periods of storage.

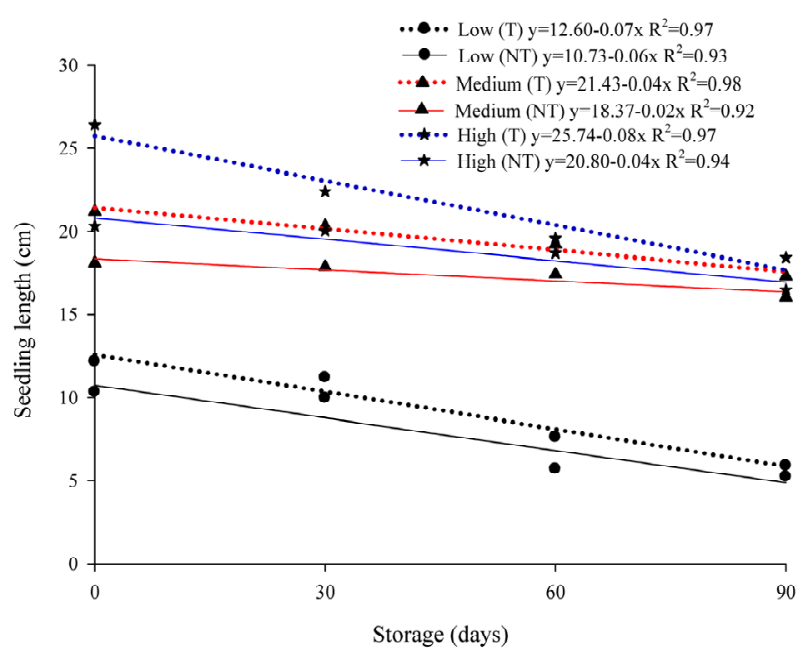

Figure 5. Polynomial regression for seedling length $(\mathrm{cm})$ derived from soybean seeds with different initial vigor levels, treated $(\mathrm{T})$ or not treated (NT) with thiamethoxam in four periods of storage.

due to the advanced deterioration degree which these seeds presented, indicating that this insecticide shows no effect as a bio-activator in low quality seeds.

An overall review of data obtained with soybean cultivar Anta suggests that, for most assessments, greater increments were reached using thiamethoxam in higher physiological quality seeds. In addition, physiological quality of soybean seeds was favored by thiamethoxam treatment, providing more expressive effects right after its application up to a 30-day storage period for treated seeds. These characteristics of thiamethoxam, along with the use of increased genetic and physiological quality seeds maximize seed production capacity. 


\section{CONCLUSION}

Soybean seed treatment using thiamethoxam favors the physiological potential of high- and medium-vigor seeds during 30-day storage. In initial low-vigor seeds, the use of thiamethoxam is inefficient in improving physiological quality.

\section{REFERENCES}

[1] Serciloto, C.M. (2002) Bioativadores de Plantas. Revista Cultivar HF, 13, 20-21.

[2] Castro, P.R.C., Pitelli, A.M.C.M., Peres, L.E.P. and Aramaki, P.H. (2007) Análise da atividade reguladora de crescimento vegetal de tiametoxam através de biotestes. Publicatio UEPG, 13, 25-29.

[3] Acevedo, J.C. and Clavijo, J. (2008) Investigación agronômica em Colombia. In: Clavijo, J., Ed., Tiametoxam: Un Nuevo Concepto em Vigor y Produtivad. Arte Litográfico, Bogotá, 41-91.

[4] Castro, P.R.C. and Pereira, M. (2008) Bioativadores na agricultura. In: Gazzoni, D.L., Ed., Tiametoxam: Uma Revolução na Agricultura Brasileira. Vozes, Petrópolis, 101-108.

[5] Castro, P.R.C. (2006) Agroquímicos de controle hormonal na agricultura tropical. Esalq, 32, 46.

[6] Clavijo, J. (2008) Tiametoxam: Um Nuevo Concepto em Vigor y Productividad. 4th Edition, Arte Litográfico, Bogotá.

[7] Cataneo, A.C. (2008). Ação do Thiametoxam sobre a germinação de sementes de soja (Glycine max L.): Enzimas envolvidas na mobilização de reservas e na proteção contra situação de estresse (deficiência hídrica, salinidade e presença de alumínio). In: Gazzoni, D.L., Ed., Tiametoxam: Uma Revolução na Agricultura Brasileira. Vozes, Petrópolis. 123-192.

[8] Khan, A.A. (1978). Incorporation of bioactive chemicals into seeds to alleviate environmental stress. Acta Horticulturae, 83, 2255-2264.

[9] Gupta, A. and Aneja, K.R. (2004) Seed deterioration in soybean varieties during storage-physiological attributes. Seed Research, 32, 26-32.

[10] Gidrol, X., Sreghini, H., Noubhani, A., Mocoquot, B. and Mazliak, P. (1989) Biochemical changes induced by accelerated ageing in sunflower seeds. Physiologia Plantarum, 76, 591-597. http://dx.doi.org/10.1111/j.1399-3054.1989.tb05484.x

[11] Silva, T.T.A., Von Pinho, E.V.R., Cardoso, D.L., Ferreira, C.A., Alvim, P.O. and Costa, A.A.F. (2008) Qualidade fisiológica de sementes de milho na presença de bioestimulante. Ciência e Agrotecnologia, 32, 840-846. http://dx.doi.org/10.1590/S1413-70542008000300021

[12] Guberac, V., Maric, S., Lalic, A., Drezner, G. and Zdunic, Z. (2003) Hermetically sealed storage of cereal seeds and its influence on vigor and germination. Journal of Agronomy and Crop Science, 189, 54-56. http://dx.doi.org/10.1046/j.1439-037X.2003.00596.x

[13] Heatherly, L.G. and Elmore, R.W. (2004) Managing in- puts for peak production. In: Boerma, H.R. and Specht, J.E., Eds., Soybeans: Improvement Production and Uses. 3rd Edition, Agronomy N-16, ASA, CSSA, Madison, 451-536.

[14] Simic, B., Popovic, S. and Tucak, M. (2004) Influence of corn bred lines seed processing on their damage. Plant Soil and Environment, 50, 157-161.

[15] Dan, L.G.M., Dan, H.A., Barroso, A.L.L., Câmara, A.C. F. and Guadanin, E.C. (2010) Efeito de Diferentes Inseticidas Sobre a Qualidade Fisiológica de Sementes de Soja. Global Science and Technology, 3, 50-58.

[16] Dan, L.G.M., Dan, H.A., Barroso, A.L.L. and Braccini, A.L. (2010) Qualidade fisiológica de sementes de soja tratadas com inseticidas sob efeito do armazenamento. Revista Brasileira de Sementes, 25, 25-28.

[17] França Neto, J.B., Krzyzanowski, F.C. and Costa, N.P. (1999) Metodologia do teste de tetrazólio em sementes de soja. In: Krzyzanowski, F.C., Vieira, R.D., França Neto, J.B., Eds., Vigor de Sementes: Conceitos e Testes. Abrates, Londrina, 1-26.

[18] Brazil Ministério da Agricultura, Pecuária e Abastecimento (2009) Regras para análise de sementes. Secretaria de Defesa Agropecuária, Brasília.

[19] Marcos Filho, J. (1999) Teste de envelhecimento acelerado. In: Krzyzanowski, F.C., Vieira, R.D. and França Neto, J.B., Eds., Vigor de Sementes: Conceitos e Testes. Abrates, Londrina, 1-24.

[20] Nakagawa, J. (1999) Testes de vigor baseados no desempenho das plântulas. In: Krzyzanowski, F.C., Vieira, R.D. and França Neto, J.B., Eds., Vigor de Sementes: Conceitos e Testes. Abrates, Londrina, 1-24.

[21] Maguire, J. D. (1962) Speed of germination-aid selection and evaluation for seedling emergence and vigor. Crop Science, 2, 176-177. http://dx.doi.org/10.2135/cropsci1962.0011183X0002000 20033x

[22] Banzatto, D.A. and Kronka, S.N. (2008) Experimentação Agrícola. 4th Edition, Funep, Jaboticabal.

[23] Brazil (2003) Lei $\mathrm{n}^{\text {o }} 10.711$ de 05 de agosto de 2003. Dispõe sobre o sistema nacional de sementes e mudas e dá outras providencias. Diário Oficial da República Federativa do Brasil, Poder Executivo, Brasília, Distrito Federal, 05 ago. 2003.

[24] Tavares, S., Castro, P.R.C., Ribeiro, R.V. and Aramaki, P.H. (2007) Avaliação dos efeitos fisiológicos de thiametoxan no tratamento de sementes de soja. Revista de Agricultura, 82, 47-54.

[25] Barros, R.G., Yokoyama, M. and Costa, J.L.S. (2001) Compatibilidade do inseticida thiamethoxan com fungicidas utilizados no tratamento de sementes de feijoeiro. Pesquisa Agropecuária Tropical, 31, 153-157.

[26] Lauxen, L.R., Villela, F.A. and Soares, R.C. (2010) Desempenho fisiológico de sementes de algodoeiro tratadas com tiametoxam. Revista Brasileira de Sementes, 32, 61-68.

http://dx.doi.org/10.1590/S0101-31222010000300007

[27] Castro, G.S.A., Bogiani, J.C., Silva, M.G., Gazola, E. and Rosolem, C. (2008) Tratamento de sementes de soja com 
inseticidas e um bioestimulante. Pesquisa Agropecuária Brasileira, 43, 1311-1318.

http://dx.doi.org/10.1590/S0100-204X2008001000008
[28] Tekrony, D.M. (1995) Accelerated ageing test. In: Van De Venter, H.A., Ed., Seed Vigour Testing Seminar. ISTA, Copenhagen, 53-72. 